\title{
Implementasi Pendidikan Karakter dalam Mata Pelajaran ISMUBA
}

\author{
Mulyono \\ Sekolah Menengah Pertama Muhammadiyah Salatiga \\ Email: mulyono@yahoo.com
}

\begin{abstract}
Abstrak
Penelitian ini bertujuan untuk mengungkapkan bagaimana implementasi pendidikan karakter ISMUBA ((Al - Islam, Muhammadiyah dan bahasa Arab) di sekolah-sekolah Muhammadiyah Salatiga pada tahun akademik 2012/2013. Dalam studi ini, peneliti menggunakan metode kualitatif dengan pendekatan beragam yaitu filosofis, fenomenologi, dan psikologi. Metode konten analisis digunakan sebagai metode analisis. Melalui metode, pendekatan dan analisis tersebut, ditemukan bahwa hal terpenting adalah implementasi pendidikan karakter di sekolah-sekolah Muhammadiyah, termasuk sekolah-sekolah Muhammadiyah Salatiga, telah ada sejak lama, sebelum hal tersebut diutarakan oleh pemerintah Indonesia. Pendidikan karakter di sekolah-sekolah Muhammadiyah diimplementasikan dalam karakter-karakter khusus mata pelajaran dengan nama ISMUBA (Al - Islam, Muhammadiyah dan bahasa Arab). Ini adalah mata pelajaran yang penting yang bertujuan dalam pembentukan karakters iswa, ini adalah karakter keislaman dalam nuansa Muhammadiyah. Saat ISMUBA sukses diaplikasikan, hal ini akan membentuk siswa yang Islami dengan semangat Muhammadiyah.
\end{abstract}

This study is aimed to reveal about how the implementation of the character education of ISMUBA (Al - Islam, Muhammadiyah and Arabic) in Salatiga Muhammadiyah schools in the academic year of 2012/2013. In this study, the researcher used qualitative methods with multiple approaches namely philosophical, phenomenological, and psychological approaches. The content analysis method is utilized as its 
analytical method. Through those methods, approaches and analysis, it was found that the most important thing is the implementation of character education in Muhammadiyah schools, including Salatiga Muhammadiyah schools, was existed since long time ago, before it was proclaimed by the Indonesia's government. Character education in Muhammadiyah schools was implemented on particular characteristics of subjects, namely ISMUBA (Al - Islam, Muhammadiyah and Arabic). This is a very significant subject which is essentially oriented in the students' character building, it is religious character (Islamic) in Muhammadiyah nuance. When ISMUBA is successful applied, it will form Islamic students with Muhammadiyah spirit.

Keywords: ISMUBA, Muhammadiyah, pendidikan karakter

\section{Pendahuluan}

Perjalanan organisasi muhammadiyah dan program pendidikannya ejak permulaan abad ke $20 \mathrm{M}$ hingga sekarang dapat di ibaratkan bagai dua sisi mata uang. Keduanya bergerak menjadi kesatuan integral yang tak dapat di pisahkan. Dalam pandangan organisasi muhammadiyah, pendidikan adalah salaah stu spectrum yang sangat pentingsehingga dapat dijadikan sebagai sarana dakwah dari persyarikatan muhammadiyah. Hal itu di topang dengan pemahaman warga persyarikatan yang tetap menempatkan dunia pendidikan sebagai salah satu upaya sadar untuk dapat membangun kualitas diri manusia pada umumnya.

Kawasan pendidikan Muhammadiyah, di antaranya terdiri dari ke Islaman, kebangsaan, keutuhan, kebersamaan, dan keunggulan merupakan suatu satu kesatuan integral yang patut dikembangkan di setiap lembaga pendidikan di bawah naungan organisasi muhammadiyah. 
Selanjutnya muncul sebuah pertanyaan kenapa keislaman ditempatkan diurutan pertama? Sebab sejauh ini salah satu ciri pendidikan dalam lingkungan muhammadiyah yang paling menonjol adalah dalam bidang agama Islam. Melalui kegiatan pendidikan ini organisasi muhammadiyah memasukkan sebuah misi pencerahan kepada masyarakat umum. Dengan karakter demikian maka lembaga-lembaga pendidikan muhammadiyah tidak ada yang tidak melaksakan butir-butir pelajaran Al Islam, keMuhammadiyahan dan bahasa Arab yang selanjutnya didefinisikan sebagai ISMUBA. Sejak awal sekolah-sekolah yang ada di bawah naungan organisasi Muhammadiyah telah memiliki materi "ISMUBA" (Al-Islam Kemuhammadiyahan dan Bahasa Arab) sebagai ciri khas lembaga pendidikan Muhammadiyah di seluruh Indonesia. Mata pelajaran tersebut merupakan mata pelajaran ciri khusus yang selalu dimaksudkan sebagai pembentuk karakter. Menurut Tasman Hamami (2012), Ketua Majelis Dikdasmen PWM DIY, ISMUBA merupakan ciri khas sekolah Muhammadiyah sebagai sebuah keseimbangan intelektual dan keagamaan, harus terus ditanamkan dalam proses belajar mengajar. Pendidikan ISMUBA memiliki motivasi dan tujuan untuk menumbuh kembangkan aqidah melalui pengamalan dan pembiasaan tentang AlIslam, mewujudkan manusia Indonesia yang taat beragama dan berakhlaqul karimah, yakni manusia yang berpengetahuan, rajin beribadah, cerdas, jujur, berdisiplin, serta mengembangkan budaya Islami dalam komunitas sekolah sesuai Al-Qur'an dan Al-Sunah. ISMUBA adalah mata pelajaran yang sangat penting karena menjadi ciri khas yang 
membedakan sekolah lainnya dengan sekolah Muhammadiyah (Suliswiyadi, 2013:72).

Pendidikan karakter yang selanjutnya akan ditanamkan dalam materi ISMUBA sekolah Muhammadiyah tak jauh berbeda dengan apa yang tertuang dalam rencana pemerintah tentang implementasi pendidikan karakter. Sebagaimana tercantum dalam Rencana Pembangunan Jangka Panjang Nasional (RPJPN) Pemerintahan RI Tahun 2005-2025, di mana pendidikan karakter ditempatkan sebagai landasan untuk mewujudkan visi pembangunan nasional, yaitu mewujudkan masyarakat berakhlak mulia, bermoral, beretika, berbudaya, dan beradab berdasarkan falsafah Pancasila. Hal ini juga tertuang dalam fungsi dan tujuan pendidikan nasional, yaitu mengembangkan dan membentuk watak serta peradaban bangsa yang bermartabat dalam rangka mencerdaskan kehidupan bangsa, bertujuan untuk berkembangnya potensi peserta didik agar menjadi manusia yang beriman dan bertaqwa kepada Tuhan Yang Maha Esa, berakhlak mulia, sehat, berilmu, cakap, kreatif, mandiri, dan menjadi warga negara yang demokratis serta bertanggung jawab" (Kemendiknas, 2011: 1-5)

Kesamaan ini menarik untuk diteliti dan dilaksanakan sebuah kajian, sekaligus dicari benang merah dan cara mengimplementasikannya. Karenanya, banyak peneliti yang telah melakukan penelitian mengenai hal ini, antara lain: Tim Penulis dari Yayasan Jati Dini Bangsa (2011: xiv), menyusun sebuah buku eksprimental Pendidikan Karakter di Sekolah dari Gagasan ke Tindakan, dari proyek rintisan pendidikan karakter di berbagai daerah. Ada 
beberapa sekolah yang menjadi kelinci percobaannya, antara lain SMP N 281, SMP N 268, SMP N 287, SMP Dian Didaktika, SMU Avivenna, dll. Buku ini merupakan hasil rekaman implementasi pendidikan karakter di beberapa sekolah tersebut.

Naniek Prihatiningtyas dalam penelitiannya Pengaruh Penerapan Pendidikan Berbasis Karakter terhadap Pengembangan Soft Skill Mahasiswa Calon Teknisi Alat Berat (2009), melaporkan bahwa ada pengaruh signifikan antara penerapan Pendidikan Berbasis Karakter (PBK) terhadap pengembangan soft skill Mahasiswa (Prihatiningtyas, 2009). Sholikah (2012), dalam penelitiannya tentang relevansi pemikiran pendidikan seorang tokoh nasional terhadap konsep pendidikan karakter.(Sholikah, 2012)

Dengan demikian, belum ditemukan satu tulisan ilmiah pun yang membahas tentang pendidikan karakter yang dikaitkan dengan ISMUBA dalam sekolah-sekolah Muhammadiyah. Oleh sebab itu, penelitian tentang masalah ini, menjadi signifikan untuk dilakukan.

Ada dua hal yang hendak diungkap melalui penelitian ini, yaitu: Pertama, Bagaimanakah konsep pendidikan karakter pada materi ISMUBA di Sekolah-sekolah di bawah naunga orgaisasi Muhammadiyah di Kota Salatiga? Kedua, Bagaimanakah implementasi pendidikan karakter dalam proses Kegiatan Belajar Mengajar ISMUBA di sekolahsekolah dibawah naungan organisasi Muhammadiyah di Kota Salatiga?

Penelitian ini akan sangat signifikan untuk dilakukan, selain untuk menjawab kedua persoalan di atas, ada beberapa hal lain yang dirasa penting maknanya, yaitu: 1) Untuk mencari benang merah antara 
konsep pendidikan karakter dengan ISMUBA, dalam rangka membentuk karakter bangsa; dan, 2) Untuk mengetahui sejauh mana implementasi pendidikan karakter di sekolah-sekolah Muhammadiyah di Kota Salatiga, terutama dipotret dari materi ciri khusus lembaga pendidikan Muhammadiyah (ISMUBA).

\section{Metode Penelitian}

Penelitian ini adalah penelitian kualitatif yang sejalan dengan apa yang dikemukakan oleh Lexy J. Moleong, bahwa penelitian kualitatif yang bermaksud untuk memahami fenomena tentang apa yang dialami oleh subjek penelitian, misalnya perilaku, persepsi, motivasi, tindakan dan lain-lain, secara holistik, dan dengan cara deskripsi dalam bentuk kata-kata dan bahasa pada suatu konteks khusus yang alamiah dengan memanfaatkan berbagai metode alamiah (2005: 6). Pemaknaan terhadap jenis penelitian ini mengikuti pemaknaan Sugiyono, bahwa metode penelitian yang digunakan untuk meneliti, obyeknya alamiah, di mana peneliti sebagai instrument kunci, teknik pengumpulan datanya secara triangulasi (gabungan), analisisnya bersifat induktif, dan hasil penelitiannya lebih menekankan makna dari pada generalisasi (Sugiyono, 2005: 1).

Sasaran penelitian ini adalah menguak konsep Pendidikan Karakter dalam ISMUBA di sekolah-sekolah dan lembaga pendidikan di bawah naungan organisasi Muhammadiyah di Kota Salatiga. Selain itu, penelitian ini juga akan menganalisa sejauh mana penerapan pendidikan karakter yang terdapat di dalam ISMUBA yang menjadi ciri khas dari 
sekolah-sekolah yang ada di dalam naungan organisasi Muhammadiyah, khususnya ada di kota Salatiga, hingga diketahui bahwa konsep pendidikan karakter itu benar-benar dapat diterapkan dalam rangka membangun karakter bangsa.

Untuk memperoleh data yang akurat mengenai obyek penelitian, maka penulis akan menggunakan ciri khas penelitian kualitatif, yaitu pengumpulan data melalui hasil pengamatan, wawancara, dan penelaahan dokumen (Moleong, 2005: 9). Penelitian ini kajiannya bersifat gabungan antara literatur dan lapangan, data primernya adalah perangkat pembelajaran guru mata pelajaran ISMUBA di Sekolah-sekolah Muhammadiyah di Kota Salatiga tahun pelajaran 2012/2013; sementara data sekundernya adalah bukti penerapan di lapangan, yang digali dari hasil observasi pembelajaran di kelas dan wawancara dengan guru pengajar ISMUBA.

Pendekatan yang digunakan dalam penelitian ini adalah pendekatan multi disipliner (multiple approach). Ada beberapa pendekatan yang akan digunakan, yaitu filosofis, fenomenologis, dan psikologis. Pendekatan filosofis adalah proses penelitian yang cermat, metodis, mendalam, evaluative, dan kritis. Pendekatan Fenomenologis adalah pendekatan yang mendasarkan analisisnya pada penampakan yang muncul ke permukaan, yang dapat diamati dan diidentifikasi. Menurut Kristensen, pendekatan ini merupakan pendekatan pelengkap dari pendekatan historis dan filosofis. Pendekatan psikologis adalah pendekatan penelitian yang didasarkan pada teori-teori psikologi. Ada dua macam prinsip dalam pendekatan ini, yaitu "lunak" dan "keras". 
"Lunak" dalam arti memberikan toleransi atas suatu kebenaran yang diyakini di masyarakat, sementara "keras" bermakna harus ada pengujian ilmiah atas setiap pernyataan kebenaran yang diyakini (Connolly, 2002: $114-201)$.

Lebih lanjut, hasil perbandingan yang telah dibuat sebelumnya, dikaji ulang dengan menggunakan metode analisis isi (content analysis) (Muhajir, 1996: 48). Isi pendidikan karakter akan dianalisa secara komparatif dengan isi ISMUBA, yaitu dengan mengindentifikasi, mensimplifikasi dan menilai data, berupa rumusan-rumusan ISMUBA dengan menggunakan pendekatan psikologis pendidikan karakter. Tentu saja penggunaan metode ini mensyaratkan adanya tiga hal, yaitu: obyektifitas, sistematis dan generalisasi (Muhajir, 1996: 49). Lalu, data yang diperoleh, akan dideskripsikan secara induktif dalam sebuah laporan hasil penelitian deskriptif.

\section{Pembahasan}

Selanjutnya akan diberikan pemaparan mengenai Pendidikan karaker sebagai berikut :

\section{A. Pengertian Pendidikan Karakter}

Istilah karakter selajutnya dapat dihubungkan dan dipertukarkan dengan istilah etika, akhlak, dan atau nilai dan berkaitan dengan kekuatan moral, berkonotasi positif, bukan netral. Sedangkan Karakter menurut Kamus Besar Bahasa Indonesia (2008) merupakan sifat-sifat kejiwaan, akhlak atau budi pekerti yang membedakan seseorang dari yang lain. Dengan demikian karakter adalah nilai-nilai yang unik-baik yang 
terpateri dalam diri dan terejawantahkan dalam perilaku. Karakter secara koheren memancar dari hasil olah pikir, olah hati, olah rasa dan karsa, serta olahraga seseorang atau sekelompok orang.

Karakter juga sering diasosiasikan dengan istilah apa yang disebut dengan temperamen yang lebih memberi penekanan pada definisi psikososial yang dihubungkan dengan pendidikan dan konteks lingkungan. Sedangkan karakter dilihat dari sudut pandang behaviorial lebih menekankan pada unsur somatopsikis yang dimiliki seseorang sejak lahir. Dengan demikian dapat dikatakan bahwa proses perkembangan karakter pada seseorang dipengaruhi oleh banyak faktor yang khas yang ada pada orang yang bersangkutan yang juga disebut faktor bawaan (nature) dan lingkungan (nurture) dimana orang yang bersangkutan tumbuh dan berkembang. Faktor bawaan boleh dikatakan berada di luar jangkauan masyarakat dan individu untuk mempengaruhinya. Sedangkan faktor lingkungan merupakan faktor yang berada pada jangkauan masyarakat dan ndividu. Jadi usaha pengembangan atau pendidikan karakter seseorang dapat dilakukan oleh masyarakat atau individu sebagai bagian dari lingkungan melalui rekayasa faktor lingkungan.

\section{B. Faktor Pendidikan Karakter}

Faktor lingkungan dalam konteks pendidikan karakter memiliki peran yang sangat peting karena perubahan perilaku peserta didik sebagai hasil dari proses pendidikan karakter sangat ditentunkan oleh faktor lingkungan ini. Dengan kata lain pembentukan dan rekayasa lingkungan 
yang mencakup diantaranya lingkungan fisik dan budaya sekolah, manajemen sekolah, kurikulum, pendidik, dan metode mengajar. Pembentukan karakter melalui rekayasa faktor lingkungan dapat dilakukan melalui strategi :

1. Keteladanan

2. Intervensi

3. Pembiasaan yang dilakukan secara Konsisten

4. Penguatan.

Dengan kata lain perkembangan dan pembentukan karakter memerlukan pengembangan keteladanan yang ditularkan, intervensi melalui proses pembelajaran, pelatihan, pembiasaan terus-menerus dalam jangka panjang yang dilakukan secara konsisten dan penguatan serta harus dibarengi dengan nilai-nilai luhur (http://pndkarakter.wordpress.com/category/tujuan-dan-fungsipendidikan-karakter/).

\section{18 Nilai Pendidikan Karakter Bangsa}

Terdapat 18 nilai-nilai dalam pengembangan pendidikan budaya dan karakter bangsa yang dibuat oleh Kemdikbud (http://www.menkokesra.go.id). Mulai tahun ajaran 2011, seluruh tingkat pendidikan di Indonesia harus menyisipkan pendidikan berkarakter tersebut dalam proses pendidikannya. 18 nilai dalam pendidikan karakter bangsa tersebut adalah:

1. Religius 
Sikap dan perilaku yang patuh dalam melaksanakan ajaran agama yang dianutnya, toleran terhadap pelaksanaan ibadah agama lain dan hidup rukun dengan pemeluk agama lain.

2. Jujur

Sikap serta perilaku yang didasarkan pada upaya menjadikan dirinya sebagai orang yang selalu dapat dipercaya dalam perkataan, tindakan, dan pekerjaan.

3. Toleransi

Sikap dan tindakan yang menghargai perbedaan agama, suku, etnis, pendapat, sikap, dan tindakan orang lain yang berbeda dengan dirinya. Dalam penanaman sikap toleransi ini banyak hal yang harus ditanamkan kepada setiap anak mengenai bagaimana hidup dengan banyak keberagaman dan kemajemukan.

4. Disiplin

Tindakan yang menunjukkan perilaku tertib dan patuh terhadap berbagai ketentuan dan peraturan. Disiplin merupakan salah satu karakter yang harus ditanamkan kepada setiap anak.

5. Kerja Keras

Tindakan yang menunjukkan perilaku tertib dan patuh terhadap berbagai ketentuan dan peraturan.

6. Kreatif

Berpikir dan melakukan sesuatu untuk menghasilkan cara atau hasil baru dari sesuatu yang telah dimiliki.

7. Mandiri 
Sikap dan perilaku yang tidak mudah tergantung pada orang lain dalam menyelesaikan tugas-tugas.

\section{Demokratis}

Cara berfikir, bersikap, dan bertindak yang menilai sama hak dan kewajiban dirinya dan orang lain.

\section{Rasa Ingin Tahu}

Sikap dan tindakan yang selalu berupaya untuk mengetahui lebih mendalam dan meluas dari sesuatu yang dipelajarinya, dilihat, dan didengar.

\section{Semangat Kebangsaan}

Cara berpikir, bertindak, dan berwawasan yang menempatkan kepentingan bangsa dan negara di atas kepentingan diri dan kelompoknya.

\section{Cinta Tanah Air}

Cara berpikir, bertindak, dan berwawasan yang menempatkan kepentingan bangsa dan negara di atas kepentingan diri dan kelompoknya.

\section{Menghargai Prestasi}

Sikap dan tindakan yang mendorong dirinya untuk menghasilkan sesuatu yang berguna bagi masyarakat, dan mengakui serta menghormati keberhasilan orang lain.

\section{Bersahabat / Komunikatif}

Sikap dan tindakan yang mendorong dirinya untuk menghasilkan sesuatu yang berguna bagi masyarakat, dan mengakui serta menghormati keberhasilan orang lain. 


\section{Cinta Damai}

Sikap dan tindakan yang mendorong dirinya untuk menghasilkan sesuatu yang berguna bagi masyarakat, dan mengakui serta menghormati keberhasilan orang lain.

\section{Gemar Membaca}

Kebiasaan menyediakan waktu untuk membaca berbagai bacaan yang memberikan kebajikan bagi dirinya. Kegemaran dalam membaca ini harus dapat ditanamkan setiap anak. Karakter gemar membaca ini merupakan salah satu kunci emas untuk dapat menciptakan generasi muda yang nantinya akan dapat menjadi salah satu tonggak masa depan sebuah bangsa. Menciptakan kegemaran dalam membaca ini harus ditanamkn sejak dini. Membaca merupakan perintah dalam al-Qur'an yang harus dijalankan setiap umat islam.

\section{Peduli Lingkungan}

Sikap dan tindakan yang selalu berupaya mencegah kerusakan pada lingkungan alam di sekitarnya, dan mengembangkan upaya-upaya untuk memperbaiki kerusakan alam yang sudah terjadi.

\section{Peduli Sosial}

Sikap dan tindakan yang selalu ingin memberi bantuan pada orang lain dan masyarakat yang membutuhkan sehingga dapat tercipta hubungan timbal balik antara setiap manusia.

\section{Tanggung Jawab}

Sikap dan perilaku seseorang untuk melaksanakan tugas dan kewajibannya, yang seharusnya dia lakukan, terhadap diri sendiri, 
masyarakat, lingkungan (alam, sosial dan budaya), negara dan Tuhan Yang Maha Esa.

\section{Sekolah Muhammadiyah di Salatiga dan Pendidikan Karakter}

Berdasarkan hasil observasi, wawancara dan pengumpulan dokumen-dokumen perangkat pembelajaran, peneliti berhasil mengumpulkan data-data penting sebagai berikut:

Pertama, keberadaan sekolah-sekolah Muhammadiyah di kota Salatiga yang terdiri dari Sekolah Dasar, Sekolah menengah Pertama, Sekolah Menengah Atas dan Sekolah Menengah Kejuruan, yang kesemuanya berada di bawah naungan Pimpinan Daerah Muhammadiyah Kota Salatiga. Pimpinan Daerah Muhammadiyah Kota Salatiga sampai saat ini memiliki amal usaha di bidang pendidikan yaitu: 1 (satu) buah SMK, 1 (satu) buah SMA, 1 (satu) buah SMP, 1 (satu) buah SD dan 5 (lima) buah TK (Aisiyah).

SMK Muhammadiyah berdiri pada tahun 1990, bertempat di Jl. KH. Ahmad Dahlan No. 2 Salatiga, melalui SK Depdikbud, Kanwil Prop. Jawa Tengah No. 384/103/I/1991, dengan NSS: 32-2-0362-04-004. SMK ini telah berkembang baik hingga tahun 2012 telah memiliki 26 lokal dan 5 bengkel, 2 laboratorium bahasa dan 1 laboratorium komputer. Pada tahun 2008 STM/SMK Muhammadiyah Salatiga menerapkan Sistem Manajemen Mutu ( SMM) ISO 9001:2000 dan pada tahun 2009 sampai dengan sekarang menerapkan SMM ISO 9001:2008 (smkmuhsala3.blogspot.com). 
SMA Muhammadiyah Salatiga didirikan pada tahun 1976, di J1. KH Ahmad Dahlan No. 1 Salatiga. Sekolah ini kini merupakan satusatunya sekolah swasta Islam di Salatiga. Sekolah ini pernah menjadi sekolah favorit di Salatiga antara tahun 1980-1990, sebelum munculnya banyak SMK di Salatiga. SMA Muhammadiyah Salatiga juga merupakan sekolah yang tetap istiqamah dalam mempertahankan jati dirinya di tengah-tengah maraknya SMA yang malih rupa menjadi SMK. Program pendidikan yang saat ini menjadi unggulan adalah Bahasa Asing, yaitu bahasa pemersatu umat Islam, Bahasa Arab. Bahasa Arab menjadi suatu kekhasan bagi sekolah Muhammadiyah yang satu ini.

SMP Muhammadiyah Salatiga berdiri pada tahun 1975 di Jalan Cempaka No. 5-7 Salatiga. Pendirian sekolah ini dikuatkan oleh SK Perwakilan Kantor Pembinaan Pendidikan Menengah Umum Departemen Pendidikan dan Kebudayaan Pemerintah Propinsi Jawa Tengah, dengan No. 243/c.2/i/74 tentang status diakuinya sebagai sekolah menengah swasta denga nomor NSS: 2020-36-20-40-18. Jumlah siswa rata-rata sejak tahun 2004-2012 mencapai 300 lebih. Tahun ini (2013) saja jumlah siswa mencapai 354 anak.

Tidak diketahui secara pasti, kapan berdirinya SD Muhammadiyah Salatiga berdiri. Sekolah ini telah berganti nama beberapa kali sejak didirikan. Pada awalnya sekolah ini bernama HIS Muhammadiyah, kemudian menjadi SR Muhammadiyah, lalu SD Muhammadiyah, dan terakhir atas prakarsa PLPM (Pengembang Lembaga Pendidikan Muhammadiyah), sejak tahun 2005 sekolah ini berubah menjadi SD Muhammadiyah Plus Salatiga. 
Kedua, upaya pembentukan karakter siswa oleh sekolah. Menurut kepala sekolah, sejak diterbitkannya surat edaran kementerian pendidikan nasional tentang implementasi pendidikan karakter, semua sekolah Muhammadiyah di Kota Salatiga telah menerapkan pembelajaran berbasis karakter. Akan tetapi, semua kepala sekolah beralasan bahwa pada dasarnya pendidikan karakter itu sudah diterapkan jauh sebelum pendidikan karakter itu dicanangkan oleh pemerintah, yakni melalui pendidikan ISMUBA.

Sekolah-sekolah Muhammadiyah di Salatiga sebagaimana sekolah-sekolah Muhammadiyah lainnya, telah menjadikan ISMUBA sebagai langkah pembentukan karakter. Seluruh materi ISMUBA didesain sedemikian rupa untuk dapat dijadikan sebagai pola pembentukan karakter pelajar Muhammadiyah. Khususnya di sekolah Muhammadiyah Salatiga materi pembelajaran ISMUBA mengikuti instruksi Pimpinan Pusat Muhammadiyah, berdasarkan Surat Keputusan Majelis Pendidikan Dasar dan Menengah (Dikdasmen) Nomor: 55/KEP/I.4/B/2007, tentang Standar Isi dan Standar Kompetensi Lulusan Pendidikan Al-Islam dan Kemuhammadiyahan (2007: 99-102).

Sementara itu, dari hasil wawancara dengan guru-guru pengajar mata pelajaran ISMUBA, diperoleh data bahwa hampir sebagian besar sudah cukup memahami tentang pentingnya pendidikan karakter di sekolah Muhammadiyah. Namun, sebagian besar dari mereka juga berpandangan bahwa ISMUBA sebagai materi pembelajaran karakter yang lebih tepat. Hanya saja selama ini, nilai-nilai karakter yang ingin disampaikan belum begitu ditegaskan. Karenanya, khusus pada materi 
ISMUBA, point-point pendidikan karakter tersebut, hanya mempertegas pembelajaran materi ISMUBA.

Di samping pembelajaran materi ciri khusus yang dikemas dalam mata pelajaran ISMUBA sekolah-sekolah Muhammadiyah di Salatiga juga menangani secara serius mengenai program-program pembentukan karakter, baik siswa maupun guru dan karyawan, sebagaimana tertera dalam rancangan program tahunan sebagai berikut : 1) Pesantren Ramadhan, Pesantren Ramadhan dilakukan setiap bulan Ramadhan selama satu minggu untuk meningkatkan ketaqwaan siswa kepada Allah SWT. Materi yang disampaikan dalam Pesantren Ramadhan adalah materi yang terkait dengan puasa, amalan selama bulan puasa, zakat fitrah dan pelaksanaan sholat idul fitri; 2) Keputrian (Kajian Al-Islam khusus putri). Kajian Al-Islam khusus putri dilaksanakan setiap minggu pada hari Jumat. Materi yang disampaikan berupa masalah-masalah yang berkaitan dengan keputrian (haid, nifas dan wiladah) serta bagaimana tata hubungan antara seorang perempuan dan laki-laki yang bukan muhrim; 3) Shalat Duha dan Jum'ah Berjama'ah. Sholat Duha dilakukan setiap hari pada jam istirahat pertama. Sedangkan sholat Jum'ah dilaksanakan di masjid terdekat dengan melibatkan guru sebagai khotib; 4) Baca Tulis al-Qur'an. Dilaksanakan seminggu sekali sesuai dengan jadwal yang ditentukan dibawah bimbingan guru ISMUBA dan tutor sebaya; (5) Tilawatil Qur'an. Dilaksanakan Seminggu sekali pada hari kamis sore sebagai bekal siswa ketika ada lomba Musabaqah Tilawatil al-Qur'an serta dijadikan bekal bagi siswa ketika berada ditengah-tengah masyarakat; 6) Hafalan dan Praktek Ibadah. Dilaksanakan di luar jam 
pelajaran sebagai kegiatan ekstrakulikuler dan dipantau lewat buku kegiatan yang diperiksa oleh guru ISMUBA secara berkala; 7) Shalat Dzuhur Berjama'ah. Dilaksanakan pada hari Senin sampai Kamis, kemudian dilanjutkan dengan kultum yang disampaikan oleh siswa secara bergantian; 8) Menjenguk teman Sakit dan Takziyah. Setiap ada teman yang sedang mengalami kesusahan (sakit atau keluarganya meninggal), maka seluruh siswa diminta untuk berinfaq untuk selanjutnya digunakan membantu meringankan beban teman yang sedang terkena musibah tersebut dan bersama-sama menjenguk atau takziyah sebagai bentuk empati; 9) Jum'at Infaq. Setiap Jumat diadakan infaq seikhlasnya untuk membantu teman-teman yang kurang beruntung dalam hal material.

Ketiga, perangkat Pembelajaran. Semua perangkat pembelajaran guru mata pelajaran ISMUBA telah dibuat berbasis karakter. Perangkatperangkat pembelajaran itu disusun mengikuti petunjuk implementasi pendidikan karakter, dengan cara menunjukkan karakter siswa yang diinginkan dalam setiap kompetensi yang ditetapkan. Cara ini sebenarnya sama dengan mata pelajaran-mata pelajaran lainnya, hanya saja untuk mata pelajaran ISMUBA, karakter tersebut hanya sekedar penegasan saja.

\section{E. Implementasi Pendidikan Karakter Sekolah Muhammadiyah}

Pendidikan Karakter sangat penting dalam upaya membentuk karakter anak bangsa yang mampu hidup dalam keragaman, cerdas, berbudaya luhur, berhati baik, kreatif dan mandiri. Hal ini tertuang dalam 
fungsi pendidikan karakter yang dicanangkan oleh pemerintah yang meliputi: 1) membangun kehidupan kebangsaan yang multikultural; 2) membangun peradaban bangsa yang cerdas, berbudaya luhur, dan mampu berkontribusi terhadap pengembangan kehidupan ummat manusia; mengembangkan potensi dasar agar berhati baik, berpikiran baik, dan berperilaku baik serta keteladanan baik; 3) membangun sikap warganegara yang cinta damai, kreatif, mandiri, dan mampu hidup berdampingan dengan bangsa lain dalam suatu harmoni (Kemendiknas, 2011: 8).

Sementara itu karakter peserta didik yang harus dimunculkan dalam suatu proses pendidikan antara lain sebagai berikut: 1) religius; 2) jujur; 3) toleransi; 4) disiplin; 5) kerja keras; 6) kreatif; 7) mandiri; 8) demokratis; 9) rasa ingin tahu; 10) semangat kebangsaan; 11) Cinta tanah air; 12) menghargai prestasi; 13) bersahabat/komunikatif; 14) cinta damai; 15) gemar membaca; 16) peduli lingkungan; 17) peduli sosial, dan; 18) tanggung Jawab (Kemendiknas, 2009: 9-10).

Karakter peserta didik semacam ini secara eksplisit telah ada dalam setiap materi ciri khas sekolah-sekolah Muhammadiyah sejak lama. Karakter ini diajarkan dan ditanamkan melalui pendidikan ISMUBA (Al-Islam, Kemuhammadiyahan dan Bahasa Arab). Pemberlakuan kurikulum 2013 yang mewajibkan kemunculan karakterkarakter di atas, semakin menguatkan eksistensi ciri khas sekolah Muhammadiyah.

Secara filosofis, fenomenologis dan psikologis, pendidikan ISMUBA ini mengacu pada tujuan berdirinya Muhammadiyah, yaitu 
untuk memurnikan ajaran Islam yang sudah banyak berbaur dengan ajaran-ajaran non-Islam. Dengan adanya pengajaran materi ini, diharapkan siswa dapat memahami Islam secara benar, dan terdorong untuk mewujudkan masyarakat Islam yang sebenar-benarnya sesuai dengan tuntunan Kanjeng Nabi Muhammad SAW, sebagaimana tertuang dalam Muqaddimah dan Anggaran Dasar Muhammadiyah.

\section{Manfaat Karakter dalam Mapel ISMUBA}

Kedelapan belas unsur karakter utama yang diharapkan muncul dalam proses pendidikan nasional, semuanya telah tercakup dalam mata pelajaran tersebut, baik secara langsung maupun tidak langsung. Misalnya pada mata pelajaran Al-Qur'an dan Al-Hadits berikut ini (Susumoyo, 2012).

\begin{tabular}{|c|c|}
\hline Kelas/Semester & $\mathrm{VII} / 1$ \\
\hline Standar Kompetensi & $\begin{array}{l}\text { 1. MemahamiQS.Al-Baqarah ayat } 1-20 \text { dan Hadis } \\
\text { Pilihan }\end{array}$ \\
\hline Kompetensi Dasar & $\begin{array}{l}\text { 1.1. Membaca QS Al-Baqarah ayat 1-20 dan menulis } \\
\text { beberapa ayat } \\
\text { 1.2. Mengartikan Mufrodad penting yang terdapat } \\
\text { dalam QS Al-Baqarah ayat } 1-20 \\
\text { 1.3. Menjelaskan isi Kandungan QS Al-Baqarah Ayat 1- } \\
\text { 20 }\end{array}$ \\
\hline Alokasi Waktu & 2 X 40 menit ( 1 pertemuan) \\
\hline Indikator & $\begin{array}{l}\text { 1. Membaca Q.S. Al-Baqarah ayat 1-20 dengan tartil } \\
\text { 2. Menulis QS. Al-Baqarah ayat 1-5 dengan baik dan } \\
\text { benar }\end{array}$ \\
\hline $\begin{array}{l}\text { Tujuan } \\
\text { Pembelajaran }\end{array}$ & $\begin{array}{l}\text { - Siswa dapat membaca tartil QS.Al-Baqarah ayat 1- } \\
20 \text { dengan baik dan benar } \\
\text { - Siswa dapat menulis Q.S.Al-Baqarah ayat } 1-5 \\
\text { dengan baik dan benar }\end{array}$ \\
\hline
\end{tabular}


Berdasarkan materi yang disampaikan (QS. Al-Baqarah:1-20), yang membahas mengenai kemurnian Al Qur'an, ciri-ciri orang bertaqwa dan ciri-ciri orang munafik, maka karakter yang diharapkan tumbuh melalui pembelajaran ini meliputi:

Pertama, Religius, penuh keyakinan (tidak ragu-ragu/percaya diri), pada ayat 1,2,3 dan 5. Kedua, tekun (menjalani suatu perbuatan tanpa ada titik jemu) dan empati, peduli sosial (berbagi pada orang lain atas dasar kasih sayang), pada ayat 3. Ketiga, responsif (tidak terkejut/heran dalam melihat kebenaran dan sesuatu yang baik), pada ayat 6 dan 7). Keempat, Jujur dapat dipercaya (tidak munafik), pada ayat 8,9 dan 10. Kelima, Bertanggung jawab dan Cita Tanah Air, Peduli Lingkungan (tidak membuat kerusakan di muka bumi), pada ayat 11 dan 12. Keenam, menghargai prestasi, pada ayat 11-20).

Dengan demikian, pendidikan karakter dalam Al-Islam, dapat dimanfaatkan sebagai penegas atas tujuan pembelajaran yang hendak dilakukan oleh para guru.

\section{Perencanaan Mapel ISMUBA Berbasis Karakter}

Perencanaan pembelajaran akan terkait erat dengan rencana pembelajaran. Perencanaan itu biasa disebut perangkat pembelajaran, yang meliputi: Kalender Akademik, Program Tahunan dan Program Semester, Standar Komptensi dan Kompetensi Dasar, Silabus dan Rencana Pembelajaran. Namun terkait dengan rencana pembelajaran, dalam hal ini peneliti akan menekankan pada persoalan Rencana Program Pembelajaran (RPP) saja, dikarenakan keterbatasan ruang untuk dimunculkan di sini. Berikut ini salah satu contoh RPP yang dibuat oleh 
guru ISMUBA di sekolah Muhammadiyah di Salatiga Tahun Pelajaran 2012/2013:

\begin{tabular}{|l|c|l|}
\hline \multicolumn{1}{|c|}{ Mata Pelajaran } & $:$ & Kemuhammadiyahan \\
\hline Kelas /Semester & $:$ & IX/1 \\
\hline Standar Kompetensi & $:$ & $\begin{array}{c}\text { F .8. Memahami Pedoman Hidup Islami } \\
\text { Muhammadiyah }\end{array}$ \\
\hline Kompetensi Dasar & $:$ & $\begin{array}{c}\text { F.8. 1. Menjelaskan bahwa manusia sebagai } \\
\text { makhluk Allah yang hidup } \\
\text { berdasarkan Tauhid }\end{array}$ \\
\hline Alokasi Waktu & $:$ & 1 X 40 menit ( 1 pertemuan) \\
\hline
\end{tabular}

Tujuan Pembelajarannya adalah agar Siswa dapat memahami Pedoman Hidup Islami Muhammadiyah (PHI). Karakter yang diharapkan antara lain dapat dipercaya (trustworthines); rasa hormat dan perhatian (respect); tekun (diligence); dan tanggung jawab (responsibility).

Metode Pembelajaran Ceramah, Demonstrasi, Tanya jawab dan CTL. Langkah-langkah Kegiatan Pembelajaran: Kegiatan Pendahuluan (Apersepsi, Guru memotivasi siswa mengenai PHI). Kegiatan Inti: Eksplorasi (Guru menjelaskan tentang Materi PHIWM). Elaborasi (Siswa menyimak, mendengarkan penjelasan dari guru). Konfirmasi (Guru bertanya jawab tentang hal-hal yang belum diktahui siswa, Guru bersama siswa bertanya jawab meluruskan kesalahan pemahaman, memberikan penguatan dan penyimpulan). Kegiatan Penutup (Guru bersama siswa melakukan refleksi mengenai kegiatan belajar dalam KD ini. Bermanfaat atau tidak? Menyenangkan atau tidak ?).

Jika dilihat dari susunan yang telah dibuat, nampaknya penyusunan program pembelajaran tersebut di atas sudah cukup baik. 
Dengan demikian, sistem pembelajaran berbasis pendidikan karakter, telah diterapkan di sekolah-sekolah Muhammadiyah di Salatiga. Selain itu, umumnya guru mapel ISMUBA di sekolah-sekolah Muhammadiyah di Salatiga, lebih suka bereksplorasi di lapangan, yang pada dasarnya telah mencakup semuanya, meskipun tidak tertulis dalam RPP. Oleh karena itu, selanjutnya peneliti akan menguraikan hasil observasi pelaksanaan di lapangan.

Selain kegiatan belajar mengajar di kelas, di sekolah-sekolah Muhammadiyah dibiasakan dengan memberikan contoh kepada siswa tentang berbagai karakter utama, misalnya disiplin. Jarang ada guru yang terlambat masuk kelas, kecuali ada hal-hal tertentu yang memaksa. Hal ini tidak terlepas dari fungsi menejerial kepala sekolah dalam memimpin lembaga pendidikan yang berada di bawah tanggung jawabnya.

Demikian pula dengan kegiatan-kegiatan penunjang, misalnya shalat berjama'ah. Para guru dan karyawan berlomba-lomba untuk datang ke masjid, ketika suara adzan berkumandang. Sehingga, para siswa ikut mengikuti kebiasaan mereka. Dengan demikian, terbentuklah karakter responsif dan disiplin.

\section{Monitoring dan Evaluasi (Monev) Mapel ISMUBA Berbasis Karakter}

Sebagai sekolah swasta yang mengandalkan kekhasan dan mutu, maka sekolah-sekolah Muhammadiyah di Kota Salatiga sangat memperhatikan kualitas lulusannya. Untuk itu, sudah pasti diperlukan adanya monitoring dan evaluasi secara berkelanjutan. Ada tiga jalur monitoring dan evaluasi yang diterapkan di sekolah-sekolah 
Muhammadiyah di kota Salatiga, yaitu Majelis Dikdasmen Muhammadiyah, Pejabat Struktural dan Masyarakat. Sejauh pengamatan di sekolah-sekolah Muhammadiyah di Salatiga, semua sistem monitoring dan evaluasi ini sudah berjalan dengan baik. Hal ini juga didukung oleh berbagai kegiatan penunjang yang juga tidak lepas dari monitoring dan evaluasi dari pihak-pihak yang berwenang.

\section{Kegiatan Penunjang Mapel Al-Islam Berbasis Karakter}

Kegiatan kegiatan penunjang, sebagaimana telah diuraikan sebelumnya, didasarkan pada mata pelajaran ISMUBA. Kegiatankegiatan tersebut, berada di bawah tanggung jawab Wakil Kepala Sekolah Bidang Al-Islam dan Kemuhammadiyahan. Berdasarkan data di atas, jelaslah bahwa kegiatan unggulan yang dilakukan di sekolahsekolah Muhammadiyah, sangat mendukung proses pembelajaran untuk menumbuhkan karakter anak bangsa yang di samping sesuai dengan ideologi Muhammadiyah, juga sejalan dengan harapan pemerintah.

Berdasarkan uraian-uraian di atas, jelas bahwa ISMUBA merupakan mata pelajaran yang sangat penting dalam membangun karakter bangsa yang diharapkan. Seluruh nilai-nilai karakter yang dijadikan sebagai ukuran keberhasilan pendidikan karakter, sebagaimana disampaikan oleh pusat kurikulum kemendiknas, telah tercover dalam pembelajaran ISMUBA di sekolah-sekolah Muhammadiyah, khususnya di Salatiga. Ke depan, bukan tidak mungkin, materi ISMUBA dapat dijadikan sebagai model pembelajaran karakter di sekolah. 


\section{Kesimpulan}

Berdasarkan hasil temuan melalui literatur-literatur terdahulu dan hasil pengamatan, pengolahan data observasi dan wawancara dapat diambil suatu kesimpulan, bahwa Melalui telaah tentang isi kurikulum ISMUBA di sekolah-sekolah Muhammadiyah Salatiga, dapat dikatakan pendidikan karakter dalam kurikulum ISMUBA sekolah Muhammadiyah Salatiga telah diformat sedemikian rupa agar sesuai dengan program pembentukan karakter yang dicanangkan oleh pemerintah.

Namun pada dasarnya konsep pendidikan karakter telah ada dalam konsep pembelajaran ISMUBA, yakni karakter yang diarahkan untuk menjadi manusia sempurna (insan kamil), sesuai dengan ajaran Islam dalam perspektif Muhammadiyah. Tujuan pembelajaran ISMUBA sendiri sejalan dengan tujuan pendidikan karakter di mana tujuan utamanya adalah terbentuknya karakter ideal bagi peserta didik. Karakter ideal yang diinginkan dalam pembelajaran ISMUBA adalah karakter religius, cerdas, mampu bekerja sama, dan peduli.

Selain itu, jika dilihat dari hasil telaah atas perangkat pembelajaran dari masing-masing guru mata pelajaran ISMUBA di sekolah-sekolah Muhammadiyah di Salatiga, dan observasi di lapangan maka dapat disimpulkan bahwa penerapan pendidikan karakter di sekolah-sekolah Muhammadiyah di Salatiga sudah berjalan cukup baik: Pertama, Semua guru telah melengkapi setiap perangkat kurikulum pembelajarannya dengan nilai-nilai karakter. Nilai-nilai karakter tersebut telah diterapkan dalam setiap kali kegiatan pembelajaran. Selain itu ada banyak sekali kegiatan tambahan dalam rangka menunjang pembelajaran 
karakter di sekolah-sekolah Muhammadiyah Salatiga. Kedua, Monitoring dan Evaluasi berjalan dengan baik melalui beberapa jalur, yaitu Pihakpihak Pemerintah terkait, Institusi sekolah, Dikdasmen, dan Masyarakat.

Ada beberapa point yang terlewatkan dari penelitian ini, misalnya konfirmasi peserta didik atas sistem pembelajaran pendidikan karakter dalam mata pelajaran ISMUBA, kemudian konfirmasi masyarakat dari hasil pendidikan karakter para siswa, dan lain-lain, yang seharusnya cukup penting dan mendukung akurasi hasil penelitian. Oleh karena itu, banyak keterbatasan dalam penelitian ini, terutama waktu dan jangkauan penelitian, maka diharapkan muncul penelitian-penelitian lainnya yang sejenis, yang lebih luas dan lebih komprehensif.

\section{Daftar Pustaka}

Connolly, Peter (ed). 2002. Aneka Pendekatan Studi Agama. Yogyakarta: LKiS.

Moleong, Lexy J. 2005. Metodologi Penelitian Kualitatif, Edidi Revisi. Bandung: PT. Remaja Rosda Karya.

Muhadjir, Noeng. 1996. Metodologi Penelitian Kualitatif. Yogyakarta: Rake Sarasin.

Muhammadiyah, Majelis Dikdasmen PP. 2007. Standar Isi dan Standar Kompetensi Lulusan Pendidikan Al-Islam dan Kemuhammadiyahan Jakarta: PP Muhammadiyah.

Prihatiningtyas, Naniek. 2009. "Pengaruh Penerapan Pendidikan Berbasis Karakter terhadap Pengembangan Soft Skill Mahasiswa Calon Teknisi Alat Berat" Tesis Program Studi Pendidikan Teknologi dan Kejuruan, Sekolah Pascasarjana Universitas Pendidikan Indonesia, Jakarta.

Sholikah. 2012."Pendidikan Karakter menurut K.H. Hasyim Asy'ari dalam Kitab Adab al-“Alim wa al-Muta'allim” Tesis, Program Studi Pendidikan Agama Islam Maulana Malik Ibrahim Malang, Malang. 
Sugiyono. 2005. Memahami Penelitian Kualitatif. Bandung: Alfabeta. Suliswiyadi. 2013. Pembelajaran Al-Islam Reflektif. UMMgl Press: GRAMASURYA.

Tim Pakar Yayasan Jati Diri Bangsa. 2011. Pendidikan Karakter di Sekolah: Dari Gagasan ke Tindakan. Jakarta: PT Elex Media Komputindo.

Tim Penyusun Pusat Kurikulum. 2009. Pengembangan dan Pendidikan Budaya dan Karakter Bangsa: Pedoman Sekolah. Jakarta: Kemendiknas.

Tim Penyusun. 2011. Panduan Pelaksanaan Pendidikan Karakter. Jakarta: Kemendiknas-Balitbang Pusat Kurikulum dan Perbukuan. 